\title{
РЕАЛИЗАЦИЯ ПРИНЦИПА ПРОФЕССИОНАЛЬНОЙ НАПРАВЛЕННОСТИ ПРИ ФОРМИРОВАНИИ КОММУНИКАТИВНЫХ КОМПЕТЕНЦИЙ СТУДЕНТОВ МЕДИЦИНСКОГО УНИВЕРСИТЕТА
}

В условиях модернизации профессионального образования одной из основных задач преподавания клинических дисциплин является формирование качественно нового уровня подготовки квалифицированного специалиста с целью его развития и становления как творческой личности, обладающей оригинальным стилем мышления, способной самостоятельно решать стоящие перед ним задачи. В связи с этим принципиально меняется позиция преподавателя клинических дисциплин. Фактически педагог создаёт условия, развивающую среду, в которой становится возможной выработка каждым студентом на его уровне развития компетенции в процессе реализации профессиональных интересов [1].

В настоящее время высокий уровень профессиональной деятельности специалиста в различных направлениях характеризуется не только профессиональными знаниями, навыками, умениями, но также развитыми социально-коммуникативными и собственнокоммуникативными способностями. В последние годы для студентов характерна слабая подготовка и слабая мотивация в изучении предметов. Одним из путей решения данной проблемы является систематическое использование профессионально направленных задании творческого и исследовательского характера на практических занятиях (разгадывание ребусов и кроссвордов) [2].

Целесообразно использовать профессионально направленные задания для формирования коммуникативной компетенции при изучении отдельных тем: «Острое нарушение мозгового кровообращения», «Демиелинизирующие заболевания», «Дегенеративно-дистрофические изменения позвоночника». Для умения пользоваться медицинским, профессиональным словарем применяется терминологический диктант. Студентам предлагается определить лексическое значение профессиональных слов и терминов: инсульт, эпилепсия, эпилептическая реак- ция, невралгия тройничного нерва, терапевтическое окно, синдром обкрадывания и другие. Студенты с интересом высказывают предположения о значениях данных слов, показывая свою осведомлённость в профессиональной сфере. В качестве внеаудиторной самостоятельной работы предлагается составить словарь профессиональных терминов. Такая работа способствует закреплению специальной терминологии, углублению профессиональных знании [3].

В процессе изучения темы «Заболевания периферической нервной системы. Неотложные состояния в неврологии» решается практическая задача формирования студентам прочных навыков оказания неотложной помощи при выраженном болевом синдроме. Студенты показывают практические навыки для выявления вертеброгенных неврологических синдромов [4].

В педагогическом процессе значительное внимание уделяется формулировке студентами клинического диагноза, который устанавливается через анализ жалоб пациента, неврологического осмотра и обследования больного. На клинической кафедре независимо от специалитета у студентов возникает интерес и помогает раскрыть их профессиональный потенциал.

В качестве дидактического материала на практических занятии используется тексты профессиональной направленности с привлечением обучающихся к подбору, поиску и отбору текстов из профессиональной периодики, специальной литературы для стимулирования познавательной активности. У студентов формируются практические навыки для понимания и усвоения материала по специальности и помогают разобраться им в специальной литературе. Ничто так не способствует развитию профессионализма обучающегося, как участие в научнопрактических конференциях, форумах, олимпи-

(c) О.Л. Максименко, Е.А. Статинова,

Ю.И. Коценко, В.С. Сохина, 2020

(c) Университетская Клиника, 2020 
адах, где необходимо представить результаты своей работы, подготовить доклад, презентацию и т.д. Реальное задание стимулирует студента к качественному его выполнению. В написании доклада, составлении тезисов и, впоследствии, публичном выступлении помогают знания, полученные при изучении дисциплины «Неврологии и медицинской генетики». В качестве внеаудиторной самостоятельной работы студенты составляют тезисы докладов по профессиональной тематике, пишут доклады, рефераты [5].
Таким образом, в процессе изучения всех разделов учебной программы по неврологии осуществляется развитие коммуникативных компетентностей обучающихся через работу над навыками профессиональной направленности. Интеграция неврологии с дисциплинами профессионального цикла убеждает студентов, что знание предмета имеет прямое отношение к выбранной ими специальности и способствует повышению мотивации к обучению и профессиональному становлению специалистов высшей школы, способных адаптироваться в современных условиях.

\section{О.Л. Максименко, Е.А. Статинова, Ю.И. Коценко, В.С. Сохина}

ГОО ВПО «Донецкий национальный медицинский университет имени М. Горького», Донецк

\section{РЕАЛИЗАЦИЯ ПРИНЦИПА ПРОФЕССИОНАЛЬНОЙ НАПРАВЛЕННОСТИ ПРИ ФОРМИРОВАНИИ КОММУНИКАТИВНЫХ КОМПЕТЕНЦИЙ СТУДЕНТОВ МЕДИЦИНСКОГО УНИВЕРСИТЕТА}

В статье раскрыта специфика формирования коммуникативных компетенции студентов медицинского университета по клинической дисциплине «Неврология» с учётом реализации принципа профессиональной направленности.
Ключевые слова: принцип профессиональной направленности; коммуникативные компетенции; профессионально- направленные задания.

\section{O.L. Maksimenko, E.A. Statinova, Yu.I. Kotsenko, V.S. Sokhina}

SEI HPE «M. Gorky Donetsk National Medical University», Donetsk

\section{IMPLEMENTATION OF THE PRINCIPLE OF PROFESSIONAL DIRECTION IN THE FORMATION OF COMMUNICATIVE COMPETENCES OF STUDENTS OF MEDICAL UNIVERSITY}

The article reveals the specifics of the formation of communicative competencies of students of a medical university in the clinical discipline "Neurology", taking into account the implementation of the principle of professional orientation.
Key words: principle of professional orientation; communicative competencies; professionally oriented tasks.

\section{ЛИТЕРАТУРА}

1. Степанов Е. Н. Личностно-ориентированный подход в работе педагога: разработка и использование. Москва: ТЦ Сфера; 2004. 128.

2. Загвязинский В.И. Инновационные процессы в образовании и педагогическая наука. Инновационные процессы в образовании: Сборник научных трудов. Тюмень; 1990: 18-19.

3. Статинова Е.А., Коценко Ю.И., Бугашев К.С. Роль интерактивных методов обучения в педагогическом процессе в медицинских университетах. Сборник научных трудов «Актуальные вопросы реабилитологии и педагогики». 2018; Т. IV, 1 (6): 183-189.

4. Максименко О.Л., Коценко Ю.И., Сохина В.С., Авсянкина Е.В. Роль и личность тьютора в высшем професси-

\section{REFERENCES}

1. Stepanov E. N. Lichnostno-orientirovannyi podkhod v rabote pedagoga: razrabotka i ispol'zovanie. Moskva: TTs Sfera; 2004. 128 (in Russian).

2. Zagvyazinskii V.I. Innovatsionnye protsessy v obrazovanii i pedagogicheskaya nauka. Innovatsionnye protsessy v obrazovanii: Sbornik nauchnykh trudov. Tyumen'; 1990: 18-19.

3. Statinova E.A., Kotsenko Yu.I., Bugashev K.S. Rol' interaktivnykh metodov obucheniya $\mathrm{v}$ pedagogicheskom protsesse v meditsinskikh universitetakh. Sbornik nauchnykh trudov «Aktual'nye voprosy reabilitologii i pedagogiki». 2018; T. IV, 1 (6): 183-189 (in Russian).

4. Maksimenko O.L., Kotsenko Yu.I., Sokhina V.S., Avsyankina E.V. Rol' i lichnost' t'yutora v vysshem professional'nom 
ональном образовании (обзор литературы). Сборник научных трудов «Актуальные вопросы реабилитологии и педагогики». 2018; T. IV, 1 (6): 102-106.

5. Статинова Е.А., Коценко Ю.И., Сохин С.А., Коценко П.И. Интерактивные методы обучения в педагогическом процессе медицинского университета. Материалы научной конференции преподавателей и аспирантов университета. Донецк; 2016: 204-207. obrazovanii (obzor literatury). Sbornik nauchnykh trudov «Aktual'nye voprosy reabilitologii i pedagogiki». 2018; T. IV, 1 (6): 102-106 (in Russian).

5. Statinova E.A., Kotsenko Yu.I., Sokhin S.A., Kotsenko P.I. Interaktivnye metody obucheniya $\mathrm{v}$ pedagogicheskom protsesse meditsinskogo universiteta. Materialy nauchnoi konferentsii prepodavatelei i aspirantov universiteta. Donetsk; 2016: 204-207 (in Russian). 